\title{
水耕培養液の窒素形態と $\mathrm{pH}$ がそ菜の銅過剩障害に及ぼす影響
}

\author{
大沢孝也・田附明夫 \\ 大阪府立大学農学部 591 堺市百舌鳥梅町
}

The Effect of Form of Nitrogen Supplied and pH Level of the

Nutrient Solution on Copper Toxicities in Vegetable Crops

Takaya Osawa and Akio Tazuke

College of Agriculture, University of Osaka Prefecture, Sakai, Osaka 591

\begin{abstract}
Summary
Bean, spinach, lettuce, and radish were grown in solution culture to investigate the effect of form of $\mathrm{N}$ supplied and $\mathrm{pH}$ level of the nutrient solution on $\mathrm{Cu}$ toxicities. Copper was supplied at levels of $0.02,0.3$, and $1 \mathrm{ppm}$. At each $\mathrm{Cu}$ level, $\mathrm{NO}_{3}, \mathrm{NO}_{3}+\mathrm{NH}_{4}(1: 1)$, and $\mathrm{NH}_{4}$ were supplied, with the total $\mathrm{N}$ concentration being held constant at 12 me/liter. The $\mathrm{pH}$ of the nutrient solution was adjusted to two levels, 4 and 6 .

1. At the normal $\mathrm{Cu}$ level $(0.02 \mathrm{ppm})$, the growth of plants supplied with $\mathrm{NO}_{3}$ and $\mathrm{NO}_{3}+\mathrm{NH}_{4}$ was excellent in any vegetable crops, but $\mathrm{NH}_{4}$ plants produced inhibited growth except for lettuce. In vegetable crops except for bean, $\mathrm{pH} 6$ produced better growth than $\mathrm{pH}$ 4. The growth reduction due to excess $\mathrm{Cu}$ in the nutrient solution was more marked at $\mathrm{pH} 4$ than at $\mathrm{pH} 6$. At $\mathrm{pH} 4, \mathrm{NO}_{3}+\mathrm{NH}_{4}$ was more advantageous than $\mathrm{NO}_{3}$ for reducing the $\mathrm{Cu}$ toxicity, while $\mathrm{NH}_{4}$ treatment did not show the same effect because of $\mathrm{NH}_{4}$ toxicity.

2. In any vegetable crops, roots were found to accumulate a larger concentration of $\mathrm{Cu}$ than leaves, the difference being more marked where excess $\mathrm{Cu}$ was supplied. The $\mathrm{Cu}$ accumulation in roots was generally larger at $\mathrm{pH} 4$ than at $\mathrm{pH}$. This was considered to be due to the markedly higher concentration of $\mathrm{Cu}^{2+}$ in the nutrient solution at $\mathrm{pH} 4$ than at $\mathrm{pH} 6$, as the result of the influence of $\mathrm{pH}$ on the extent of chelate formation of $\mathrm{Cu}$ with EDTA supplied as Fe-EDTA. The application of $\mathrm{NH}_{4}$ had effects to suppress the $\mathrm{Cu}$ accumulation in roots. In $\mathrm{NO}_{3}$ and $\mathrm{NO}_{3}+\mathrm{NH}_{4}$ treatments, there was a close relationship between the $\mathrm{Cu}$ accumulation in roots and the reduction of plant growth. The root $\mathrm{Cu}$-plant growth relationship in $\mathrm{NH}_{4}$ treatment was quite different from that in $\mathrm{NO}_{3}$ and $\mathrm{NO}_{3}+\mathrm{NH}_{4}$ treatments; especially in spinach and radish, the plant growth was almost constantly poor regardless of the root $\mathrm{Cu}$ concentration.
\end{abstract}

\section{緒言}

著者の一人，大沢はこれまでそ菜について，必須微 量重金属元素である $\mathrm{Mn}, \mathrm{Zn}, \mathrm{Cu}$ の過剩障害に関する 一連の水耕試験を行ってきたが, $\mathrm{Cu}$ は他の 2 元素と異 なって根に高濃度に蓄積し, とくに根に著しい障害を 与えるのが特徵的であった(8)。 また $\mathrm{Fe}(11) や \mathrm{Ca}(12)$ のようなカチオン要素の適度の增施は, $\mathrm{Cu}$ の吸収を拮 抗的に抑制して, $\mathrm{Cu}$ 過剩障害を軽減する効果のあるこ とを認めた。このような観点から，そ菜の主要な $\mathrm{N}$ 給

1990 年 6 月 8 日 受理。そ菜の重金属過剩障害に関する 研究. 第 12 報.
源であるアニオンの $\mathrm{NO}_{3}-\mathrm{N}$ とカチオンの $\mathrm{NH}_{4}-\mathrm{N}$ が, $\mathrm{Cu}$ 過剩障害にどのように影響するかを比較検討するこ とは興味ある問題である。 Mn $\mathrm{Zn}$ が過剩の場合に, $\mathrm{NH}_{4}{ }^{+}$や $\mathrm{H}^{+}$がそ菜による $\mathrm{Mn} や \mathrm{Zn}$ の吸収を抑制し, 過㮃障害を軽減する効果のあることは既に報告した $(9$, 10).一方 Tills・Alloway (14) は $\mathrm{NH}_{4}{ }^{+}$がコムギなど の $\mathrm{Cu}$ 吸収を抑制する効果を認めている.

そこで本報では, 前述のように Mnや $\mathrm{Zn}$ とは障害の 機作がやや異なる $\mathrm{Cu}$ 過剩の発生に及ぼす, 培盖液の $\mathrm{N}$ 形態と $\mathrm{pH}$ の影響について検討するため，4 種そ菜を供 試して水耕試験を行った結果を報告する. 


\section{材料及び方法}

供試そ菜は第 1 表に示した 4 種類で, Hoagland 第 1 液を用いて養液育苗した。

水耕はガラス室内において, 直径 $42 \mathrm{~cm}$ で約 $15 l$ 容 のプラスチック製容器を用い，木製のふたに小孔をあ けて植物体をさしこみ，必要に応じて植物体を支柱で 保持して行った. 1 容器当たり $14 l$ の培養液を与え, ブロワーを用いて通気した，1容器当たりの株数は， インゲンマメは 4 株, ホウレンソウ, レタスは 8 株, ハツカダイコンは 16 株で，いずれも 1 区 2 容器とした。 処理区の構成は, $\mathrm{Cu}$ は $0.02,0.3,1 \mathrm{ppm}$ の 3 レ ベル, $\mathrm{N}$ は全 $\mathrm{N}$ 濃度を $12 \mathrm{me} / l$ 一定として $\mathrm{NO}_{3}$, $\mathrm{NO}_{3}+\mathrm{NH}_{4}(1: 1), \mathrm{NH}_{4}$ の 3 区, $\mathrm{pH}$ は 4,6 の 2 レべ ルとし，これらを組み合わせて合計 18 処理区を設けた。 なお， $\mathrm{Cu} 0.02 \mathrm{ppm} \cdot \mathrm{NO}_{3} \cdot \mathrm{pH} 6$ の区を標準区とし た.

共通基本培養液は $\mathrm{KH}_{2} \mathrm{PO}_{4}: 1, \mathrm{~K}_{2} \mathrm{SO}_{4}: 2$, $\mathrm{MgSO}_{4}: 2, \mathrm{CaCl}_{2}: 4 \mathrm{mM}$ の組成とし, 微量要素は $\mathrm{Fe}(\mathrm{Fe}-\mathrm{EDTA} に よ): 3, \mathrm{~B}: 0.5, \mathrm{Mn}: 0.5$, $\mathrm{Zn}: 0.05, \mathrm{Mo}: 0.01 \mathrm{ppm}$ を与えた。 この共通基本培 養液に $\mathrm{CuSO}_{4}$ を所定の濃度に加用して $\mathrm{Cu}$ 濃度処理を 行った.また $\mathrm{NaNO}_{3}$ と $\left(\mathrm{NH}_{4}\right)_{2} \mathrm{SO}_{4}$ を所定の濃度に施 用することにより $\mathrm{N}$ 処理を行った。培養液の $\mathrm{pH}$ は $1 \mathrm{~N}$

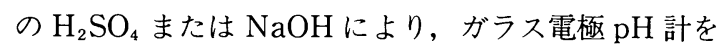
用いて毎日 1 回調節した。培養液の作成や蒸発散によ る液の減量分の補給には, 比抵抗 $10^{6} \Omega / \mathrm{cm}$ 以上の脱 塩水を用いた。

処理期間は第 1 表に示したように，そ菜の種類によっ て異なった。培養液の更新は週 1 回行った。

栽培期間中に随時, 外観症状を調査した。またイン ゲンマメでは開花日を 5 日ごとのグループに区切り, 各グループのさやをその最終開花日から 12 日後にまと めて合計 3 回収穫し, 収量調査ののち, $70^{\circ} \mathrm{C}$ で数日間 熱風乾燥して乾物収量を求めた。 いずれのそ菜も水耕 打切り後収穫した植物体は, 生育調査を行ったのち部 位別に熱風乾燥し乾物重を求めた。乾物試料は粉砕し
てデシケータ中に保存し，分析に供した，分析は乾燥 粉末試料 $250 \mathrm{mg}$ を, $550^{\circ} \mathrm{C}$ の電気炉中で灰化したのち, $1: 1 \mathrm{HCl}$ で溶解し, 万過後 $50 \mathrm{ml}$ の定容とした供試液 について, $\mathrm{Cu}$ を原子吸光分光分析法により定量した. また NCアナライザーにより全Nを定量した。

\section{生育・収量}

\section{結果}

第 1 図は 4 種そ菜について $\mathrm{pH}$ 別に, $\mathrm{Cu}$ 濃度・N形 態処理が生育・収量に及ぼす影響を示したものである。 まず各 $\mathrm{pH}$ で $\mathrm{Cu}$ 標準レベル(0.02 ppm)における N形態 処理の影響についてみると, 各そ菜とも $\mathrm{NO}_{3}, \mathrm{NO}_{3}+$ $\mathrm{NH}_{4}$ 両区では生育良好であったが，多くの場合後者の 方がより優れた。 $\mathrm{NH}_{4}$ 区ではレタス以外の 3 種そ菜は 著しく生育不良で，インゲンマメは枯死をきたした。 $\mathrm{Cu}$ 標準レベルの各 $\mathrm{N}$ 形態区における $\mathrm{pH}$ の影響は，イ ンゲンマメ以外の 3 種そ菜で認められ，いずれも $\mathrm{pH} 6$ の方が生育が優れ，とくにホウレンソウでその傾向が 著しかった。

$\mathrm{Cu}$ 処理が $\mathrm{pH}$ 及びN形態との関連において，生育. 収量に及ばした影響は次のようであった。まず pH 6 に ついて各 $\mathrm{N}$ 形態区ごとにみると，4種そ菜とも $\mathrm{Cu}$ 処理 によってそれほど著しい生育阻害をきたさなかった。 なお $\mathrm{NH}_{4}$ 区においては，レタス以外の 3 種そ菜では $\mathrm{Cu}$ 害より $\mathrm{NH}_{4}$ 害による生育阻害の方が問題であった。し かし pH 4 では $\mathrm{Cu}$ 害の様相は著しく異なり， $\mathrm{NO}_{3}$ 区で は 4 種そ菜とも $\mathrm{Cu} 1 \mathrm{ppm}$ 処理で著しい生育阻害をきた し, $\mathrm{NO}_{3}+\mathrm{NH}_{4}$ 区においてもインゲンマメ以外の 3 種 そ菜では同様であった。なお $\mathrm{pH} 4$ における $\mathrm{NO}_{3}$, $\mathrm{NO}_{3}+\mathrm{NH}_{4}$ 両区を比較すると, インゲンマメとレタス では $\mathrm{Cu} 0.3$ 及び $1 \mathrm{ppm}$ 処理において，また他の 2 種そ 菜では $\mathrm{Cu} 0.3 \mathrm{ppm}$ 処理において, $\mathrm{NO}_{3}+\mathrm{NH}_{4}$ 区の方が $\mathrm{Cu}$ による生育阻害を軽減する効果を示すことから有利 であった。しかし $\mathrm{NH}_{4}$ 区は， $\mathrm{NH}_{4}$ 耐性の強いレ夕スで も $\mathrm{Cu}$ 害を軽減する効果を示さなかった。 なお, $\mathrm{Cu}$ 過 剩条件下に护る各 $\mathrm{N}$ 形態区の生育を両 $\mathrm{pH}$ 間で比較す ると, 多くの場合 $\mathrm{pH} 6$ の方が優れた.

第 1 表. 供試材料と処理期間.

\begin{tabular}{|c|c|c|c|}
\hline 種 & 品 & $\begin{array}{l}\text { 処理開始時 } \\
\text { 展開本葉数 }\end{array}$ & 処理期間 \\
\hline インゲンマメ & つるなし丸さや三度豆 & 2 枚 & 51 日 \\
\hline ホウレンソウ & ニュー・アジア & 4 & 26 \\
\hline レタス & グレート・レークス 366 & 5 & 28 \\
\hline ハツカダイコン & コメット & 2 & 21 \\
\hline
\end{tabular}



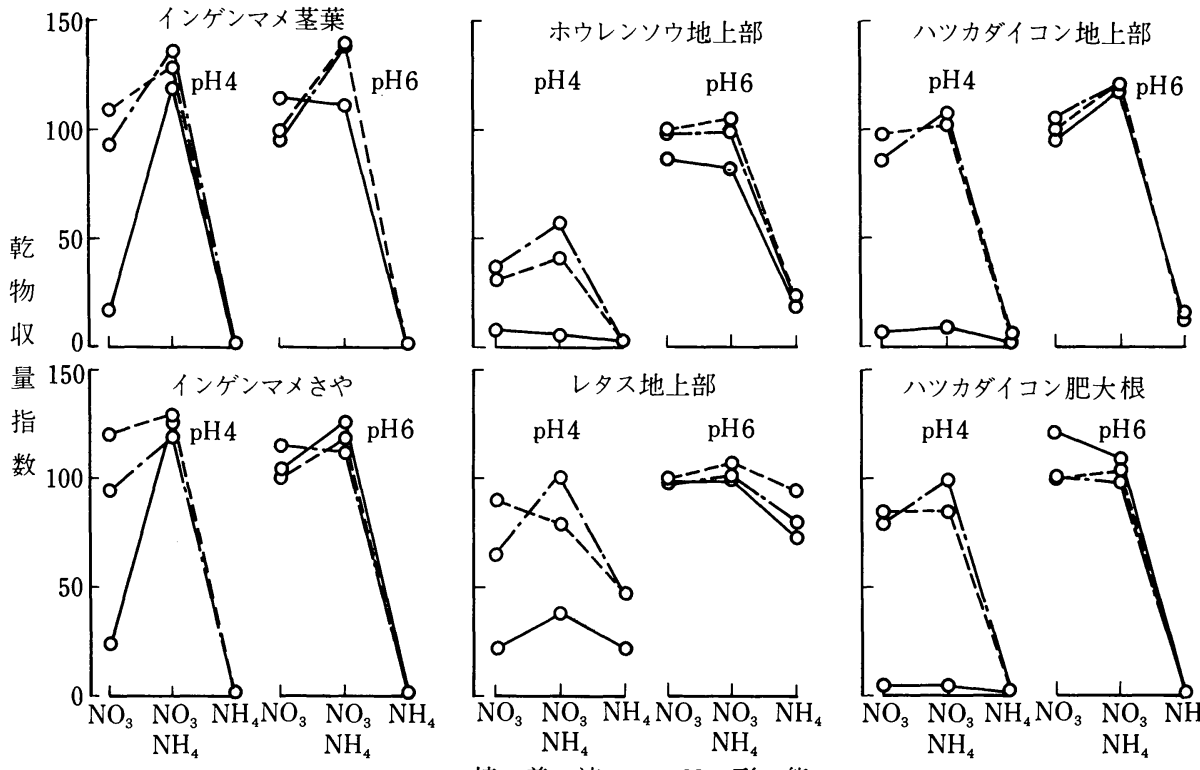

培養液 の $\mathrm{N}$ 形 態

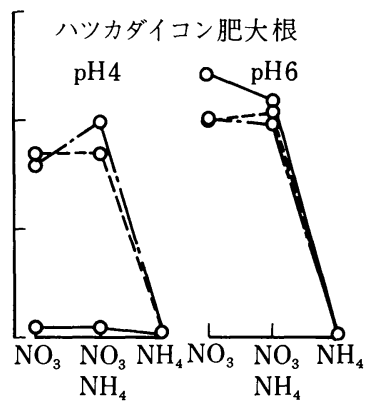

$\mathrm{Cu}$ 濃度

$0.02 \mathrm{ppm}$

$-0.3 \mathrm{ppm}$

$-1 \mathrm{ppm}$

第 1 図. 培養液の $\mathrm{pH}, \mathrm{Cu}$ 濃度, $\mathrm{N}$ 形態が 4 種そ菜の生育・収量に及ぼす影響.

乾物収量指数は $\mathrm{pH} 6 \cdot \mathrm{Cu} 0.02 \mathrm{ppm} \cdot \mathrm{NO}_{3}$ 区を 100 とする.

$\mathrm{Cu}$ 害症状は主として根に現れ，とくに生育阻害の著 しかった処理区では，根はかっ変して伸長が阻害され， 獅子尾状根が観察された。

\section{植物体の分析結果}

第 2 表に 4 種そ菜の葉中全 $\mathrm{N}$ 含有率を示した。同一 の $\mathrm{pH} \cdot \mathrm{Cu}$ レベルで， $\mathrm{NO}_{3}$ 区と $\mathrm{NO}_{3}+\mathrm{NH}_{4}$ 区を比較 すると，多くの場合後者の方が全 $\mathrm{N}$ 含有率が高かった. $\mathrm{NH}_{4}$ 区については，レタス以外の 3 種そ菜は生育が極 端に悪いため同列には論じられない。そこでレタスの $\mathrm{NH}_{4}$ 区についてみると，おおむね他の 2 区より全N含 有率は高かった。 $\mathrm{Cu}$ 処理や $\mathrm{pH}$ が全 $\mathrm{N}$ 含有率に及ぼす 影響については，明らかな傾向は認められなかった。

第 3 表に 4 種そ菜の部位別の $\mathrm{Cu}$ 含有率を示した。葉 と根(ハツカダイコンでは細根)を比べると, 同一条件 下では根の方が $\mathrm{Cu}$ 含有率が高く，その較差は $\mathrm{Cu}$ 高濃 度区ほど大きかった。インゲンマメのさや，ハツカダ イコンの肥大根の $\mathrm{Cu}$ 含有率は, 葉とほぼ同レベルであっ た。このように植物体に吸収された $\mathrm{Cu}$ は根に高濃度に 蓄積したので，とくに根中 $\mathrm{Cu}$ 含有率に及ぼす処理の影 響についてみると次のようである.まず同一 $\mathrm{pH} \cdot \mathrm{Cu} レ$ ベルで $\mathrm{NO}_{3}$ 区と $\mathrm{NO}_{3}+\mathrm{NH}_{4}$ 区を比較すると，多くの 場合後者の方が $\mathrm{C}$ u含有率が低かった。 $\mathrm{NH}_{4}$ 区は, 生
育が比較的良好であったレタスについてみると，他の 2 区より低い $\mathrm{Cu}$ 含有率であった。すなわち $\mathrm{NH}_{4}$ の施用 割合の増加は $\mathrm{Cu}$ 吸収，ひいては根中の $\mathrm{Cu}$ 蓄積を抑制 する効果があった。一方，pHの影響についてみると， 同一条件下ではおおむね $\mathrm{pH} 4$ の方が $\mathrm{pH} 6$ よりも根中 $\mathrm{Cu}$ 含有率が高く，その差は $\mathrm{Cu}$ 高濃度区において著し かった.

第 2 図は 4 種そ菜について, $\mathrm{pH}$ 別に根中 $\mathrm{Cu}$ 含有率 と地上部の生育との関係を示したものである. $\mathrm{NO}_{3}$, $\mathrm{NO}_{3}+\mathrm{NH}_{4}$ 両区においては，一般に根中 $\mathrm{Cu}$ 含有率が 高いほど生育阻害が著しく，またこの関係は両区間で 差がないといえる。しかし， $\mathrm{NH}_{4}$ 区では上記の 2 区と は著しく異なった関係がみられ，とくにホウレンソウ 及びハツカダイコンでは， $\mathrm{Cu}$ 含有率とは無関係に生育 量がほぼ一定して低かった。

\section{考 察}

培養液中の $\mathrm{Cu}$ 濃度が標準レベル $(0.02 \mathrm{ppm})$ の場合, 一般に $\mathrm{NO}_{3}, \mathrm{NO}_{3}+\mathrm{NH}_{4}$ 両区に比べて $\mathrm{NH}_{4}$ 区が生育 不良であったことは従来の報告 $(4,5,9,10)$ と同様であ る.なお， $\mathrm{NO}_{3}$ 区と $\mathrm{NO}_{3}+\mathrm{NH}_{4}$ 区のいずれの生育が優 れるかは，そ菜の種類，培地組成など種々の要因で変 わることが考えられるが，今回の試験では多くの場合 


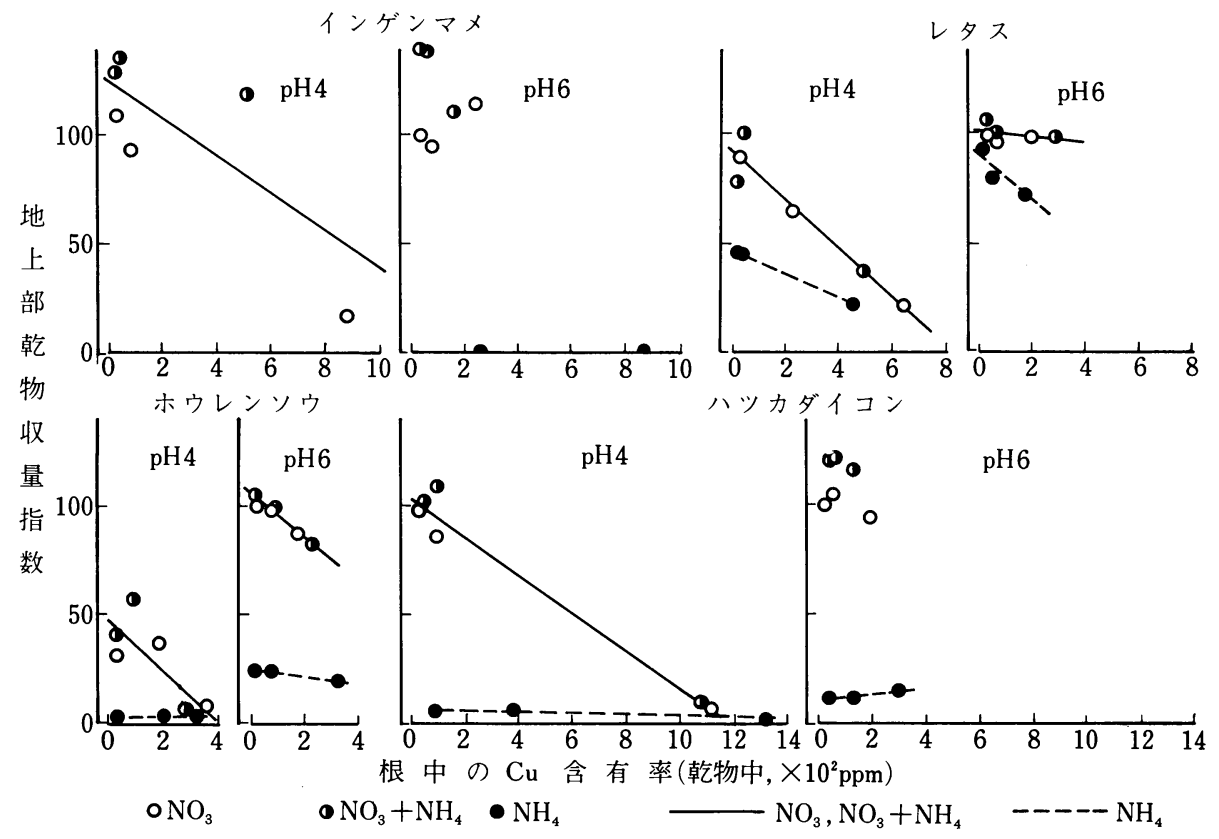

第 2 図. $\mathrm{pH}, \mathrm{Cu}, \mathrm{N}$ 形態処理を行った 4 種そ菜の根中 $\mathrm{Cu}$ 含有率と地上部の生育との関係. 地上部乾物収量指数は第 1 四の注を参照.

第 2 表。培養液の $\mathrm{pH} ， \mathrm{Cu}$ 濃度， $\mathrm{N}$ 形態が 4 種そ菜の葉中全 $\mathrm{N}$ 含有率に及ぼす影響。

\begin{tabular}{|c|c|c|c|c|c|c|}
\hline \multirow{2}{*}{\multicolumn{2}{|c|}{$\begin{array}{c}\stackrel{\text { 処 }}{\mathrm{pH}} \cdot \mathrm{Cu} \cdot \\
(\mathrm{ppm})\end{array}$}} & \multirow{2}{*}{$\begin{array}{c}\text { 理 } \\
\mathrm{N} \text { 形態 }\end{array}$} & \multicolumn{4}{|c|}{ 全 $\mathrm{N}$ 含有率（乾物中\%） } \\
\hline & & & インゲンマメ & ホウレンソウ & レタス & ハツカダイコン \\
\hline \multirow{9}{*}{4} & \multirow{3}{*}{0.02} & $\mathrm{NO}_{3}$ & 4.09 & 5.79 & 5.10 & 6.68 \\
\hline & & $\mathrm{NO}_{3}+\mathrm{NH}_{4}$ & 4.44 & 6.02 & 5.10 & 7.00 \\
\hline & & $\mathrm{NH}_{4}$ & $\longrightarrow$ & 3.87 & 6.08 & 6.92 \\
\hline & \multirow{3}{*}{0.3} & \multirow{3}{*}{$+\mathrm{NH}_{4}$} & 4.04 & 5.85 & 4.41 & 6.88 \\
\hline & & & 4.36 & 6.17 & 5.90 & 6.94 \\
\hline & & & - & 3.37 & 5.48 & 6.87 \\
\hline & \multirow{3}{*}{1} & \multirow{3}{*}{$\begin{array}{l}\mathrm{NO}_{3} \\
\mathrm{NO}_{3}+\mathrm{NH}_{4} \\
\mathrm{NH}_{4}\end{array}$} & 4.20 & 3.44 & 3.11 & 4.97 \\
\hline & & & 4.44 & 3.40 & 4.87 & 5.43 \\
\hline & & & - & 3.24 & 4.73 & 5.33 \\
\hline \multirow{9}{*}{6} & \multirow{6}{*}{0.02} & \multirow{3}{*}{$\begin{array}{l}\mathrm{NO}_{3} \\
\mathrm{NO}_{3}+\mathrm{NH}_{4} \\
\mathrm{NH}_{4}\end{array}$} & 4.12 & 5.72 & 4.84 & 6.91 \\
\hline & & & 4.03 & 5.59 & 5.48 & 7.01 \\
\hline & & & - & 6.81 & 5.75 & 7.10 \\
\hline & & \multirow{3}{*}{$\begin{array}{l}\mathrm{NO}_{3} \\
\mathrm{NO}_{3}+\mathrm{NH}_{4} \\
\mathrm{NH}_{4}\end{array}$} & 4.32 & 5.74 & 5.48 & 6.84 \\
\hline & & & 4.46 & 6.20 & 5.27 & 7.00 \\
\hline & & & 4.75 & 6.70 & 5.93 & 7.08 \\
\hline & \multirow{3}{*}{1} & \multirow{3}{*}{$\begin{array}{l}\mathrm{NO}_{3} \\
\mathrm{NO}_{3}+\mathrm{NH}_{4} \\
\mathrm{NH}_{4}\end{array}$} & 4.29 & 5.63 & 5.36 & 6.82 \\
\hline & & & 4.66 & 6.13 & 5.78 & 6.69 \\
\hline & & & 5.20 & 6.24 & 5.96 & 7.01 \\
\hline
\end{tabular}

$z$ —は植物体の枯死による欠測. 
$\mathrm{NO}_{3}+\mathrm{NH}_{4}$ 区の方が優れた。また $\mathrm{Cu}$ 標準レベルの各 $\mathrm{N}$ 形態区における $\mathrm{pH}$ の影響は，インゲンマメ以外の 3 種そ菜で認められ，いずれも $\mathrm{pH} 6$ の方が $\mathrm{pH} 4$ よりも 生育が優れ，とくに゙ウレンソウでその傾向が著しかっ た。

$\mathrm{Cu}$ 過剩条件下における各そ菜の生育反応に関して, 先ず注目すべきことは $\mathrm{pH}$ の影響であった。すなわち， 最高 $1 \mathrm{ppm}$ までの Cu 濃度処理による生育阻害は, pH 6 ではそれほど問題でなかったが，pH 4 ではしばし ば著しく認められ, $\mathrm{pH} 6$ より生育が劣った。また $\mathrm{pH} 4$ では, $\mathrm{NO}_{3}$ 区と $\mathrm{NO}_{3}+\mathrm{NH}_{4}$ 区とは $\mathrm{Cu}$ 害の発生に対し て明らかに異なった影響を及ぼした。すなわち，イン ゲンマメとレタスでは $\mathrm{Cu} 0.3$ および $1 \mathrm{ppm}$ 処理にお いて, また他の 2 種そ菜では $\mathrm{Cu} 0.3 \mathrm{ppm}$ 処理において, $\mathrm{NO}_{3}+\mathrm{NH}_{4}$ 区の方が $\mathrm{Cu}$ による生育阻害を軽減する効 果があり有利であった。しかし $\mathrm{NH}_{4}$ 区は， $\mathrm{NH}_{4}$ 耐性の 強いレタスでもそのような効果を示さなかった，以上 を要するに, $\mathrm{Cu}$ 害は $\mathrm{pH} 6$ より $\mathrm{pH} 4$ において著しく,
また $\mathrm{pH} 4$ では, $\mathrm{NO}_{3}$ 区に比べて $\mathrm{NO}_{3}+\mathrm{NH}_{4}$ 区は $\mathrm{Cu}$ 害 を軽減する効果により有利であった。

このように $\mathrm{Cu}$ 過剩条件下で $\mathrm{pH} 4$ の方が $\mathrm{pH} 6$ より も不利であったことは, 既報の $\operatorname{Mn}(9) や Z n(10)$ の過 剩障害の試験結果とは逆の傾向であった。 すなわち $\mathrm{Mn}$ や Zn が過剩の場合には, 同一のN処理区の生育はしば しば $\mathrm{pH} 4$ の方が $\mathrm{pH} 6$ よりも優れたが，このことは $\mathrm{H}^{+}$ がカチオンとして Mn や Zn の吸収を拮抗的に抑制する 効果によるものと理解された. 一方, 今回の試験では, おおむね $\mathrm{pH} 4$ の方が $\mathrm{pH} 6$ よりも植物体とくに根の $\mathrm{Cu}$ 含有率が高く, $\mathrm{Cu}$ 害が著しいという結果となっており, $\mathrm{Cu}$ 吸収に対しては $\mathrm{H}^{+}$による拮抗的な効果は認められ なかった。これらの現象には, 茅野 (1), Guinn·Joham (3), 武長ら（13）が報告しているような, 溶液中の重金 属と鉄キレートの反応に及ぼす $\mathrm{pH}$ の影響が関与すると 考えられる。 Guinn・Joham (3)は, $\mathrm{pH} 6$ の溶液中に $\mathrm{Fe} 2 \mathrm{ppm}$ が Fe-EDTA として存在しているところへ, $\mathrm{Cu} 1 \mathrm{ppm}$ を $\mathrm{CuSO}_{4}$ として加えた場合を想定して論じて

第 3 表. 培盖液の $\mathrm{pH}, \mathrm{Cu}$ 濃度, $\mathrm{N}$ 形態が 4 種そ菜の植物体中 $\mathrm{Cu}$ 含有率に及ぼす影響.

\begin{tabular}{|c|c|c|c|c|c|c|c|c|c|c|c|c|c|}
\hline \multirow{3}{*}{\multicolumn{2}{|c|}{$\begin{array}{c}\text { 処 } \\
\mathrm{pH} \cdot \mathrm{Cu} \cdot \\
(\mathrm{ppm})\end{array}$}} & \multirow{3}{*}{$\mathrm{N}$ 形態 } & \multicolumn{11}{|c|}{$\mathrm{Cu}$ 含有率（乾物中 $\mathrm{ppm} ）$} \\
\hline & & & \multicolumn{4}{|c|}{ インゲンマメ } & \multicolumn{2}{|c|}{ ホウレンソウ } & \multicolumn{2}{|c|}{ レタス } & \multicolumn{3}{|c|}{ ハツカダイコン } \\
\hline & & & 葉 & 茎 & 巳やz & 根 & 葉 & 根 & 葉 & 根 & 葉 & 肥大根 & 細根 \\
\hline \multirow{9}{*}{4} & \multirow{3}{*}{0.02} & $\mathrm{NO}_{3}$ & 15 & 15 & 15 & 26 & 10 & 26 & 16 & 26 & 17 & 7 & 24 \\
\hline & & $\mathrm{NO}_{3}+\mathrm{NH}_{4}$ & 14 & 13 & 14 & 19 & 12 & 18 & 11 & 11 & 22 & 6 & 41 \\
\hline & & $\mathrm{NH}_{4}$ & $\longrightarrow$ & - & 一 & - & 11 & 38 & 8 & 11 & 24 & 29 & 77 \\
\hline & \multirow{3}{*}{0.3} & $\mathrm{NO}_{3}$ & 16 & 17 & 16 & 74 & 38 & 162 & 26 & 221 & 19 & 22 & 88 \\
\hline & & $\mathrm{NO}_{3}+\mathrm{NH}_{4}$ & 23 & 17 & 18 & 47 & 29 & 86 & 16 & 40 & 14 & 21 & 89 \\
\hline & & $\mathrm{NH}_{4}$ & - & - & - & - & 30 & 199 & 13 & 31 & 28 & 79 & 376 \\
\hline & \multirow{3}{*}{1} & $\mathrm{NO}_{3}$ & 75 & 58 & 40 & 876 & 40 & 349 & 26 & 642 & 62 & 130 & 1112 \\
\hline & & $\mathrm{NO}_{3}+\mathrm{NH}_{4}$ & 72 & 46 & 28 & 516 & 49 & 278 & 36 & 496 & 63 & 140 & 1092 \\
\hline & & $\mathrm{NH}_{4}$ & - & - & - & - & 41 & 317 & 31 & 461 & 74 & 175 & 1326 \\
\hline \multirow{9}{*}{6} & \multirow{6}{*}{0.02} & $\mathrm{NO}_{3}$ & 18 & 16 & 16 & 28 & 17 & 22 & 18 & 32 & 13 & 4 & 22 \\
\hline & & $\mathrm{NO}_{3}+\mathrm{NH}_{4}$ & 15 & 14 & 14 & 27 & 16 & 21 & 12 & 20 & 11 & 4 & 59 \\
\hline & & $\mathrm{NH}_{4}$ & - & - & - & - & 14 & 16 & 11 & 16 & 18 & 21 & 40 \\
\hline & & \multirow{3}{*}{$\begin{array}{l}\mathrm{NO}_{3} \\
\mathrm{NO}_{3}+\mathrm{NH}_{4} \\
\mathrm{NH}_{4}\end{array}$} & 18 & 18 & 16 & 71 & 24 & 70 & 18 & 56 & 18 & 12 & 49 \\
\hline & & & 18 & 19 & 20 & 61 & 22 & 89 & 19 & 55 & 13 & 11 & 46 \\
\hline & & & 38 & 23 & 72 & 256 & 30 & 74 & 19 & 48 & 15 & 61 & 127 \\
\hline & \multirow{3}{*}{1} & $\mathrm{NO}_{3}$ & 24 & 28 & 17 & 234 & 19 & 166 & 20 & 191 & 24 & 23 & 194 \\
\hline & & $\mathrm{NO}_{3}+\mathrm{NH}_{4}$ & 21 & 20 & 17 & 149 & 25 & 209 & 29 & 288 & 20 & 59 & 122 \\
\hline & & $\mathrm{NH}_{4}$ & 28 & 38 & 52 & 861 & 43 & 316 & 29 & 173 & 41 & 99 & 293 \\
\hline
\end{tabular}

$z$ 第 3 回収穫物の分析結果.

$y$ 一は植物体の枯死による欠測. 
いるが, $\mathrm{Fe}$ と $\mathrm{Cu}$ が置きかわることにより, 全 $\mathrm{Cu} の$ 92\%が Cu-EDTA として存在することを示している. 今回の試験では, pH 4, 6の2レベルにおいて, Fe 3 $\mathrm{ppm}$ を Fe-EDTA として与え, Cu を最高 $1 \mathrm{ppm}$ 加え た。 そこで上記の Guinn らの手法に従い，また錯生成 反応に対する $\mathrm{pH}$ の影響(6)も考慮に入れて, Cu $1 \mathrm{ppm}$ 加用の場合における $\mathrm{Cu}$ と EDTA の錯結合の比率を計 算したところ，第 3 図に示したようであった．即ち， $\mathrm{Cu}$ は $\mathrm{pH} 6$ では約 $95 \%$ がキレート態となるため $\mathrm{Cu}^{2+}$ は 少ないが, pH 4 では逆に殆どキレート化せずにイオン 状態であるという結果が得られた。このように $\mathrm{Cu}$ と EDTAの結合は, $\mathrm{pH}$ 4 6の範囲では $\mathrm{pH}$ 依存性が強 く, pH 4 では pH 6 に比べて $\mathrm{Cu}^{2+}$ の濃度がはるかに高 いため, $\mathrm{Cu} の$ 吸収ひいては $\mathrm{Cu}$ 害が著しく, 結果とし て $\mathrm{H}^{+}$にる拮抗が現れなかったと理解される. $\mathrm{Cu}^{2+}$ $\mathrm{Cu}$-EDTAの害作用の比較に関しては, Majumder • Dunn(7)はトウモロコシについて, Cu-EDTAの方が 害が軽度なことを認め，また Guinn·Joham (2) は，ワ 夕の根中 $\mathrm{Cu}$ 含有率が EDTA の添加によって減少した ことを報告している。なお，既報の $\operatorname{Mn}(9), \operatorname{Zn}(10)$ の 試験結果と比較考察するため, $\mathrm{H}^{+}$による拮抗がしばし ば認められた Mn $100 \mathrm{ppm}$ 及び Zn $30 \mathrm{ppm}$ の場合につ いて，上記と同様の手法で計算したところ，第 3 困に 示したよjに, いずれも $\mathrm{pH} 4$ 4 6範囲では, 殆ど或 いは大部分がイオン状態であるという結果が得られた。

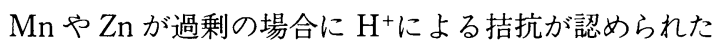
のは, このような理由によるものと思われる.

一方 $\mathrm{pH} 4$ の場合, $\mathrm{NO}_{3}$ 区に比べて $\mathrm{NO}_{3}+\mathrm{NH}_{4}$ 区の 方が $\mathrm{Cu}$ 害を軽減して有利であったのは, $\mathrm{NH}_{4}{ }^{+}$が $\mathrm{Cu}^{2+}$

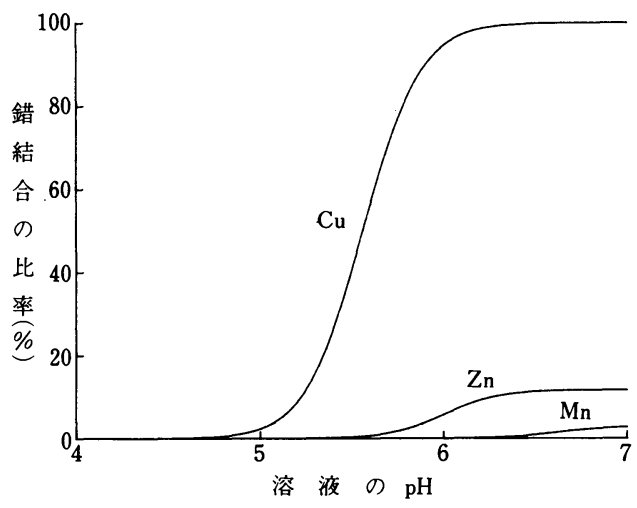

第 3 図. Fe-EDTA 溶液中に重金属塩を加えた場合に重金属が EDTA と錯結合する比率に及ほす $\mathrm{pH}$ の影響に関するシ ミュレーション.ただし Fe 濃度は $3 \mathrm{ppm}$, 重金属濃度 は $\mathrm{Cu} 1, \mathrm{Zn} 30, \mathrm{Mn} 100 \mathrm{ppm}$ とする。
の吸収を拮抗的に抑制したためと考えられ，既報の $\mathrm{Mn}$ (9)やZn(10)の過剩障害の場合と同様であった。ただ, $\mathrm{Cu}$ の場合は根に高濃度に蓄積し, 主として根に障害を 与えるタイプであるため，とくに根中の $\mathrm{Cu}$ 蓄積の抑制 が害軽減に有効であったと思われる。 なお $\mathrm{NH}_{4}$ 区では たとえ $\mathrm{Cu}$ 吸収が抑制されても， $\mathrm{NH}_{4}$ 害の方が問題であ るため, $\mathrm{Cu}$ 害軽減効果が認められなかったものと思わ れる。このことは，第 2 図に示した根中 $\mathrm{Cu}$ 含有率と生 育との関係からも裏付けられよう。

\section{摘 要}

培養液の $\mathrm{N}$ 形態と $\mathrm{pH}$ がそ菜の $\mathrm{Cu}$ 過㮃障害に及ぼす 影響について検討するため, インゲンマメ，ホウレン ソウ,レタス, ハツカダイコンを供試して水耕試験を 行った. $\mathrm{Cu}$ は 0.02, $0.3,1 \mathrm{ppm} の 3$ レベル， Nは全 $\mathrm{N}$ 濃度を $12 \mathrm{me} / l$ 一定として $\mathrm{NO}_{3}, \mathrm{NO}_{3}+\mathrm{NH}_{4}(1$ : 1), $\mathrm{NH}_{4}$ の 3 区, $\mathrm{pH}$ は 4, 6の 2 レベルとし, これら の組み合わせによる 18 処理区を設けた。

1. $\mathrm{Cu}$ 標準レベル $(0.02 \mathrm{ppm})$ における生育は, 各そ 菜とも $\mathrm{NO}_{3}, \mathrm{NO}_{3}+\mathrm{NH}_{4}$ 両区では良好なのに対して, $\mathrm{NH}_{4}$ 区ではレタス以外は著しく劣った。またインゲン マメ以外では, $\mathrm{pH} 6$ の方が $\mathrm{pH} 4$ より生育が優れた。

$\mathrm{Cu}$ 高濃度処理による生育阻害は, $\mathrm{pH} 6$ よりも $\mathrm{pH} 4$ の 方が著しかった。 $\mathrm{pH} 4$ では， $\mathrm{NO}_{3}$ 区よりも $\mathrm{NO}_{3}+\mathrm{NH}_{4}$ 区の方が $\mathrm{Cu}$ 害を軽減する効果を示すことから有利で あったが, $\mathrm{NH}_{4}$ 区では $\mathrm{NH}_{4}$ 害のため同様の効果は認め られなかった。

2. 各そ菜とも葉より根に高濃度の $\mathrm{Cu}$ を蓄積し, そ の較差は $\mathrm{Cu}$ 高濃度区ほど大きかった。また根中の $\mathrm{Cu}$ 蓄積は，おおむね $\mathrm{pH} 6$ より $\mathrm{pH} 4$ の方が著しかった。 これは培養液中の $\mathrm{Cu}$ と $\mathrm{Fe}$ に随伴する EDTA の錯結 合が $\mathrm{pH}$ に影響される結果, $\mathrm{pH} 4$ の方が $\mathrm{Cu}^{2+}$ 濃度が著 しく高いためと考えられた. $\mathrm{NH}_{4}$ 施用は根中の $\mathrm{Cu}$ 蓄積 を抑制する効果があった。一般に $\mathrm{NO}_{3}, \mathrm{NO}_{3}+\mathrm{NH}_{4}$ 両 区では, 根中の $\mathrm{Cu}$ 蓄積と生育阻害との間に等しく密接 な関係が認められた。しかし， $\mathrm{NH}_{4}$ 区ではこれら両区 と著しく異なった関係がみられ，とくにホウレンソウ とハツカダイコンでは, 根中 $\mathrm{Cu}$ 含有率とは無関係に生 育量がほぼ一定して低かった。

謝辞 本稿を草するに当たり貴重な助言を頂い た東京大学農学部教授茅野充男博士, 並びに大阪府立 大学工学部青木豊明博士に深謝の意を表する.また本 研究の遂行に際して助力を与えられた宮島希代子君に 謝意を表する。 


\section{引用文 献}

1. 茅野充男. 1967. 重金属元素の植物に対する害 作用特に重金属誘導鉄クロロシスの発生機構に 関する研究. 茨大農学術報告. 15：105-164.

2. Guinn, G. and H. E. Joham. 1962. Effects of two chelating agents on absorption and translocation of $\mathrm{Fe}, \mathrm{Cu}, \mathrm{Mn}$, and $\mathrm{Zn}$ by the cotton plant. Soil Sci. 94 : 220-223.

3. Guinn, G. and H. E. Joham. 1963. Displacement of iron from ferric ethylenediaminetetraacetic acid and ferric hydroxyethylethylenediaminetriacetic acid by copper and zinc. Soil Sci. 95 : 101-104.

4. 池田英男 - 大沢孝也. 1979. 施用窒素形態とそ 菜の適応性. (第 1 報). 水耕栽培において硝酸, アンモニア，亜硝酸を窒素源とした果菜の生育 並びに窒素同化. 園学雑. 47：454-462.

5. 池田英男 - 大沢孝也. 1980. 施用窒素形態とそ 菜の適応性. (第 2 報). 水耕栽培において硝酸, アンモニア，亜硝酸を窒素源とした葉菜の生育 並びにアンモニア態および硝酸態窒素蓄積の差 異. 園学雑. $48 ： 435-442$.

6. 河合 聡 - 木下俊夫 - 辻 章夫 - 渡辺光男. 1982. 定量分析化学. p.191-193. 丸善. 東京.

7. Majumder, S. K. and S. Dunn. 1959. Modifying effect of EDTA on copper toxicity to corn in nutrient solution. Plant in.d Soil $10: 296-298$.

8. 大沢孝也・池田英男. 1974. そ菜の重金属過㮃 障害に関する研究。(第 4 報)。水耕培養液中の 銅濃度がそ菜の生育に及ぼす影響. 園学雑. $43: 267-272$.

9. 大沢孝也・池田英男. 1980 . そ菜の重金属過剩 障害に関する研究. (第 8 報)。水耕培養液の窒 素形態と $\mathrm{pH}$ がそ菜のマンガン過剩障害に及ぼす 影響. 園学雑. 49：197-202.

10. 大沢孝也・池田英男. 1985. 水耕培養液の窒素 形態と $\mathrm{pH}$ がそ菜の亜鉛過剰障害に及ぼす影響. 園学雑. 53 : 427-431.

11. 大沢孝也.池田英男. 1989. 水耕培養液中の鉄 濃度がそ菜の銅過剩障害に及ぼす影響. 園学雑. $58: 673-678$.

12. 大沢孝也 - 田附明夫. 1990. 水耕培養液中の力 リ，カルシウム濃度がそ菜の銅過剩障害に及ぼ す影響. 園学雑. 59：365-370.

13. 武長 宏・牧田幸三・麻生末雄. 1971. フミン 酸の肥効発現に関する研究. (第 6 報). 鉄・銅 イオン共存時におけるニトロフミン酸のキレー 卜作用について. 土肥誌. $42 ： 286-290$.

14. Tills, A. R. and B. J. Alloway. 1981. The effect of ammonium and nitrate nitrogen sources on copper uptake and amino acid status of cereals. Plant and Soil 62 : 279-290. 